\title{
Patho-physiological studies of human blood with kidney dysfunction and therapeutics of albumin functionalized silver nanoparticles in mice kidney cells in vitro
}

\author{
T Anitha Sironmani* and Anil Bhattarai \\ School of Biotechnology, Madurai Kamaraj University, Madurai 625021, India
}

\begin{abstract}
The incidence of acute kidney injury and disease is increasing alarmingly. Inflammatory or nutritional status are associated with kidney disease/ Serum albumin is the marker to identify malnutrition in patients with chronic kidney disease. Treatment with albumin functionalized green synthesized silver nanoparticles help maintain and restore normal cellular function in the kidney. The role of albumin in kidney cell metabolism was studied in-vitro and showed a profound influence of albumin with or without nanoparticles on the level of protein, glucose, and catalase activity. The albumin-nanoparticle treated cells were observed to be healthier as evidenced from the morphology of the cells. Elevated levels of $66 \mathrm{kDa}, 59 \mathrm{kDa}, 45 \mathrm{kDa}, 34,29 \mathrm{kDa}$ proteins were observed. The proteins may be Heat shock proteins which has cytoprotective properties. The antimicrobial properties of the silver nanoparticles control the infection and inflammation. This novel nanopreparation could lead to the new therapeutics in the treatment of renal injury restoring renal function.
\end{abstract}

\section{Research highlight}

- Hypoalbuminemia, is highly prevalent in kidney failure and is associated with an increased mortality risk reflecting either the inflammatory or nutritional status of patients

- To understand the relationship between malnutrition and serum albumin dosed through functionalized silver nanoparticles the current study was carried out in patients with illness and in organ culture using mice kidney in vitro.

- The Albumin functionalized silver nanoparticles were effective combating inflammation and degradation of cellular and extracellular matrix, transporting nutrition to the damaged nephrons prompting self-repair to maintain the status of protein and fat metabolism to avoid dialysis and to support the kidney to work properly preventing acute renal failure.

- Besides, the nanoformulation strengthen the immune system to fight chronic problems reducing the oxidative stress and infection preventing acute renal failure.

\section{Introduction}

Kidney disease is closely associated with protein-calorie malnutrition [1-3]. Serum albumin is the principal nutritional marker used to identify malnutrition in patients with chronic kidney disease (CKD). Hypoalbuminemia, is highly prevalent in kidney failure and is associated with an increased mortality risk in this population may be reflecting either the inflammatory or nutritional status of patients [4-7], though appetite suppression and enhanced protein catabolism by proinflammatory cytokine. Prevalence of acidosis and inflammation and their association with low serum albumin in chronic kidney disease is reported by Joseph, et al. [8]. A loss of renal function/dysfunction results from hypoxia -failure of tissue oxygen delivery, decrease glomerular filtration and filtered sodium load, by a fall in tubular sodium reabsorption [9] and consequently, oxygen consumption [10-13].

An illness or inflammatory state can reduce serum albumin levels by suppressing synthesis, increasing catabolism and/or vascular permeability to albumin, or a combination of these [14-16]. Patients with chronic kidney disease (CKD) shows increased metabolic activities resulting in high oxidative stress and acute phase inflammation due to infection $[17,18]$. A vital role for catalase in the defense against oxidantmediated renal fibrosis is reported by Kobayashi, et al. [19].

To understand the relationship between malnutrition and serum albumin dosed through functionalized silver nanoparticles the current study was carried out in patients with illness and in organ culture using mice kidney in vitro. Specialised nanoformulation prepared using combination of herbal and protein extracts. These are effective combating inflammation and degradation of cellular and extracellular matrix, transporting nutrition to the damaged nephrons prompting self-repair to maintain the status of protein and fat metabolism to avoid dialysis and to support the kidney to work properly preventing acute renal failure. Besides, the nanoformulation strengthen the immune System to fight chronic problems reducing the oxidative stress and infection preventing acute renal failure.

Correspondence to: T Anitha Sironmani, School of Biotechnology, Madurai Kamaraj University, Madurai 625021, India, Tel: 9104522458273/994214614; E-mail: asironmani@gmail.com; a_sironmani@yahoo.co.in

Key words: nanotreatment, kidney dysfunction, silver nanopreparation, albumin, kidney protein profile, in vitro kidney analysis renal nutrition

Received: January 20, 2018; Accepted: February 13, 2018; Published: February 16,2018 


\section{Materials and methods}

\section{Sample collection}

Blood samples were collected from suspected kidney patients from Chekkanurani, Madurai, TamilNadu, India and the sera were analyzed for biochemical factors like- protein, glucose, albumin and catalase activity.

\section{Preparation and characterization of silver nanoparticles}

Synthesis of Silver nanoparticles and functionalization with albumin was done as reported earlier [20] with modification. The nanoparticles were characterized using UV-visible spectrophotometer and FTIR

\section{Primary culture of kidney cells}

In order to understand the effects of albumin, silver nanoparticles and both kidney was dissected from Swiss mice and homogenized in saline solution and cultures with fresh RPMI medium as following: $2 \mathrm{~K}$ Control(C);2AK-Cells+Albumin;2BK-Cells+Albumin+Nanosolution were grown for four days at $37^{\circ} \mathrm{C}$ Finally, cells were harvested for further studies.

\section{Biochemical tests}

All biochemical tests were carried out using standard procedures already reported.

\section{Labelling of kidney cells for confocal microscopic study}

Albumin endocytosis by kidney cells were visualized by confocal microscopy. Mouse kidney cells were incubated with $(3 \mathrm{mg} / \mathrm{ml}$ Rhodamine B-albumin for $1 \mathrm{~h}$, washed, fixed in paraformaldehyde, and fluorescence was visualized by confocal microscopy. Image is representative of 3 experiments. The harvested cells were quantified for fluorescence in Fluorescence spectrophotometer.

\section{SDS-PAGE}

The protein profiles of the various samples were analyzed by running $12.5 \%$ SDS-PAGE for both blood and kidney samples.

\section{Results}

Albumin transports numerous substances including free fatty acids, certain ions, bilirubin and many drugs. The fall in albumin concentration in turn affects the plasma oncotic pressure which in turn results in acute illness. Changes in the amount of albumin can influence renal function. The mechanism behind this effect is still unknown. Hence, it was attempted to study the role of albumin in renal function in vitro as well as in renal failure problematic patient's blood. An attempt to analyze the therapeutic potential nanoparticles was also initiated. The present study shows the effect of albumin functionalized silver nanoparticles on the kidney cells in vitro.

\section{Synthesis and characterization of silver nanoparticles}

Figure 1a shows the TEM analysis of the albumin functionalized silver nanoparticles. Approximately $20 \mathrm{~nm}$ sized particles were observed. The nanoparticles were characterized using UV-visible spectrometer (Figure $1 \mathrm{~b}$ and FTIR (Figure 1c)) to verify the stability and bonding of the nanoparticles respectively.

\section{Studies with human blood sample}

The blood samples collected from suspected kidney patients were analyzed for protein level, glucose level, albumin level and catalase activity to get a marker for early diagnostics and therapeutics. Figure 2 (A-C) shows the Albumin, protein and glucose concentration of control and experimental samples. The Catalase activity of different samples is shown in Figure 2D. The high levels of protein, glucose, albumin may lead to the development of certain diseases like diabetes, cardiovascular diseases, renal failure, etc. The glucose, protein and albumin concentrations were found to be high compared to the control. In contrast to that, the catalase activity was low in the experimental samples.

The protein profile pattern of blood sample collected from suspected kidney patients were analysed on $12.5 \%$ SDS-PAGE (Figure 3). Low concentration of $34,29,25$, and $23 \mathrm{kDa}$ protein was observed in 2 samples. Third sample showed higher level of expression of those proteins compared to the control blood.

\section{In vitro animal studies}

The role of albumin in kidney cell metabolism was studied invitro and showed a profound influence of albumin with or without nanoparticles on the level of protein, glucose, catalase activity and protein profile of the samples.

Kidney was dissected from Swiss mice and was homogenized and cultured as mentioned in material and methods. Figure 4 (A-C) shows different morphological forms of kidney cells. The albuminnanoparticle treated cells were healthy as evidenced from the morphology of the cells and no dead cells were observed by viable staining (Data not shown).

The various biochemical factors like-protein, glucose, albumin and catalase activities were analyzed (Figure 5). The comparative activity in fold difference (Figure 5) of the catalase was found to be down regulated. Nanoparticle with albumin treated cells showed high glucose, protein and albumin level. A decrease in catalase activity was observed. Compared to the control minimum difference was observed in albumin treated kidney cells and a 0.5 -fold increase of all biochemical factors in nanoparticle and albumin treated kidney cells.

The test samples were also analyzed to check the protein profile pattern by running 12.5\% SDS-PAGE (Figure 6) which showed unusual loss of $34,29,25 \& 23 \mathrm{kDa}$ protein in 2 samples whereas third sample showed higher level of protein expression as compared to the controlled blood. The elevated level of high molecular weight proteins $66 \mathrm{kDa}$ and $59 \mathrm{kDa}$ protein along with 34, $29 \mathrm{kDa}$ protein were observed (Lane E2).

Albumin endocytosis by kidney cells were visualized by confocal microscopy. To test the functional status of mouse kidney cells treated with Rhodamine B-albumin for $1 \mathrm{~h}$ and observed under confocal microscopy (Figure 7). Epithelial-like phenotype cells without any injury or mortality were observed. The fluorescence spectrum revealed (Figure 8) a reduction in the fluorescence showing the less accumulation of nanoparticles in the kidney sample. Silver nanoparticles fluoresce because of surface Plasmon resonance and the background fluoresces was controlled by the presence of albumin-nanoparticles.

\section{Discussion}

Kidney disease is closely associated with protein calorie malnutrition. Serum albumin is the principal nutritional marker used to identify malnutrition in patients with chronic kidney disease (CKD). Albumin serves in the transport of hormones, metals, vitamins, and drugs contributing to the oncotic pressure. Changes in the amount of albumin can influence renal function. Nanomedicine 

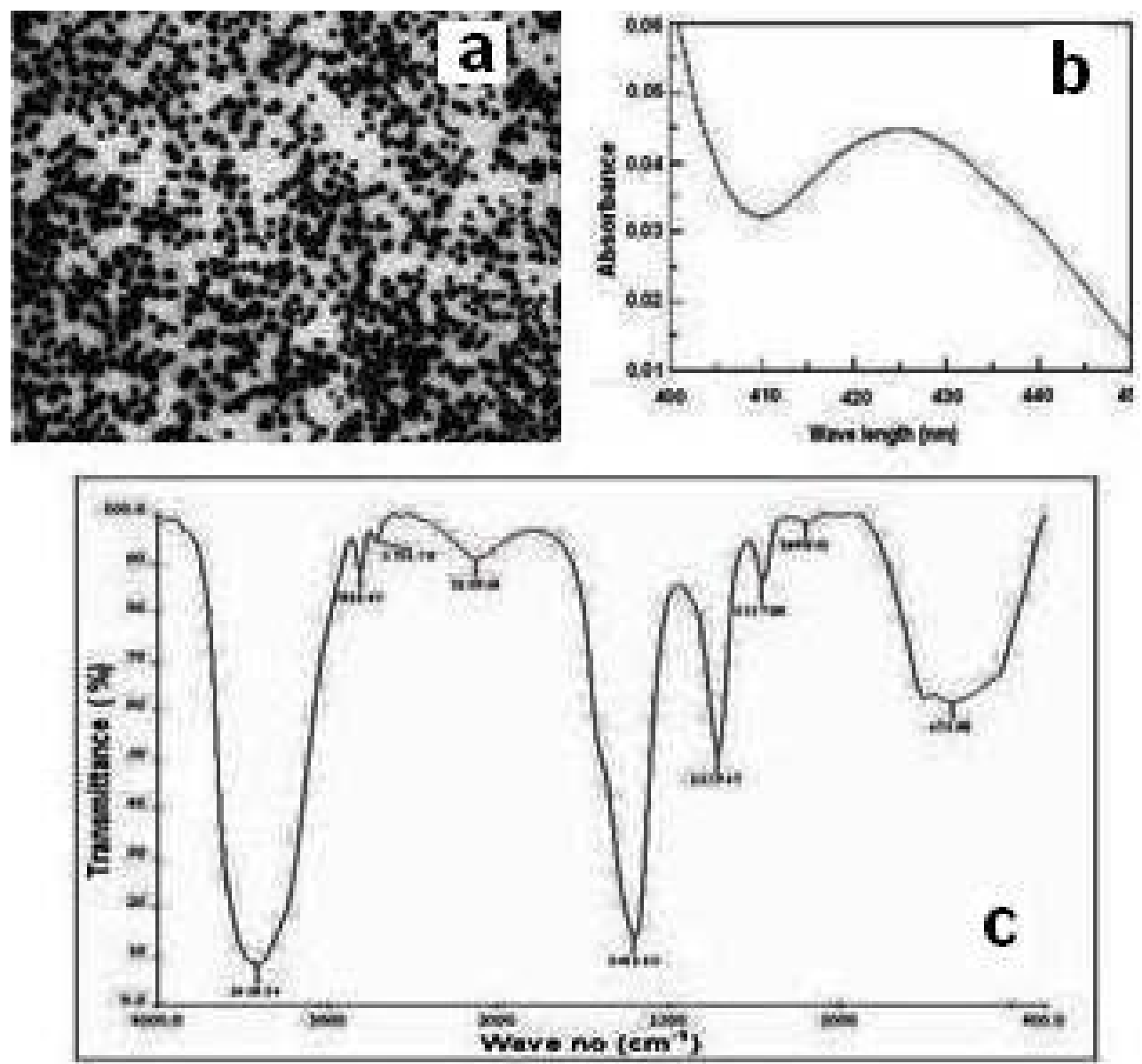

Figure 1. The characterization of albumin functionalized silver nanoparticles (a) TEM analysis (b) UV-visible spectrum of the nanoparticles (c) FTIR analysis
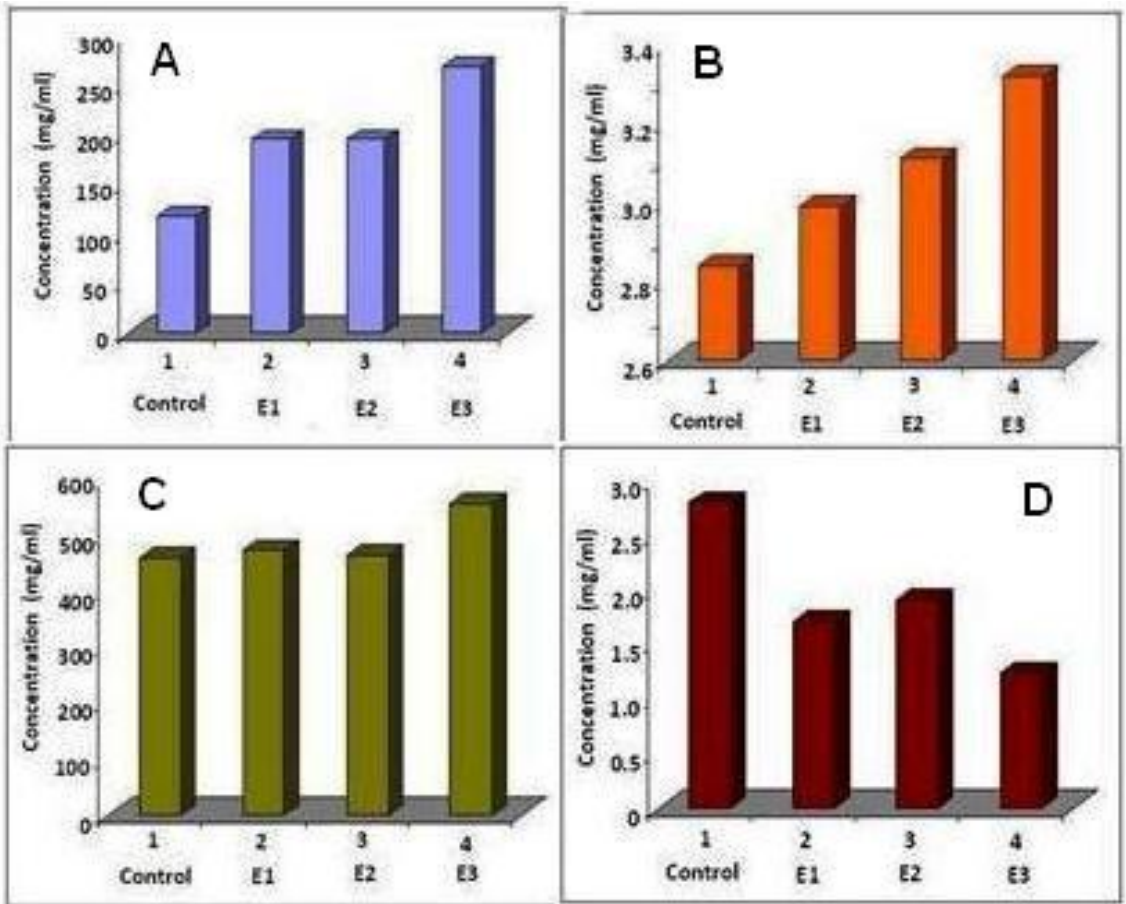

Figure 2. Biochemical analysis of blood samples from suspected patients with kidney problems. (A) Protein level (B) Albumin level (C) Glucose level and (D) Catalase activity 


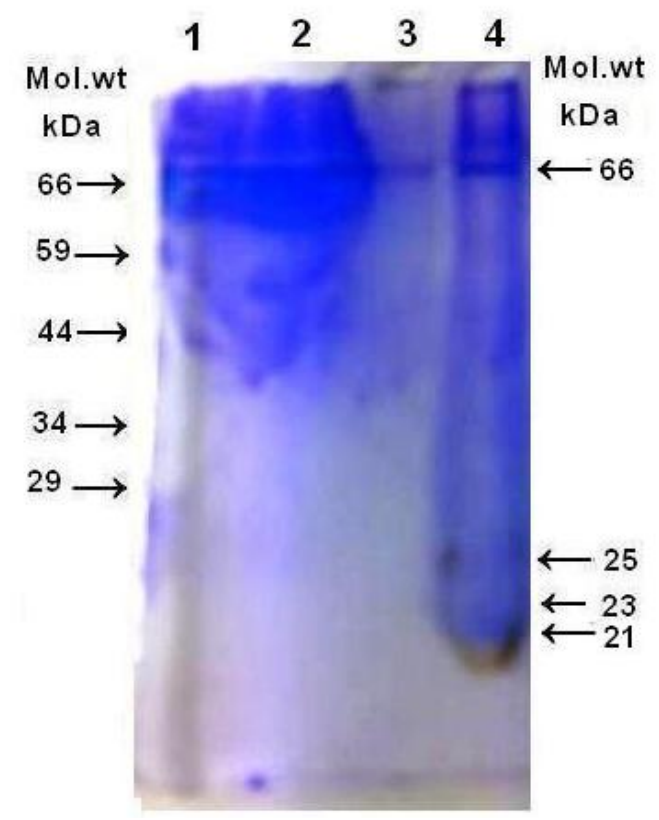

Figure 3. The protein profile of blood sample fractionated through $12.5 \%$ SDS-PAGE

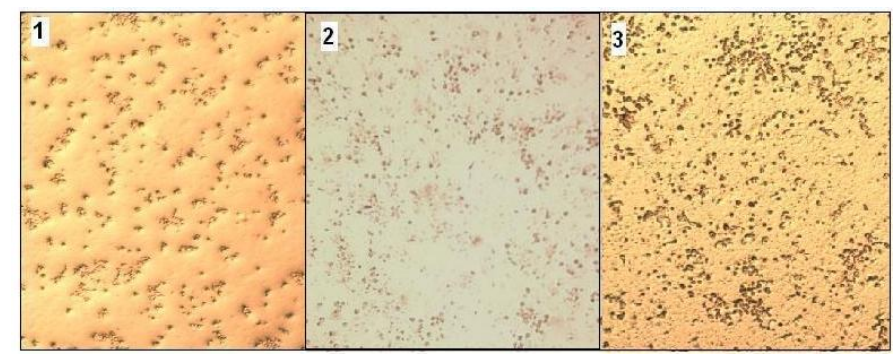

Figure 4. Morphology of kidney cells 1. Control 2. Albumin treated 3. Albumin- Silver nanoparticle treated cells

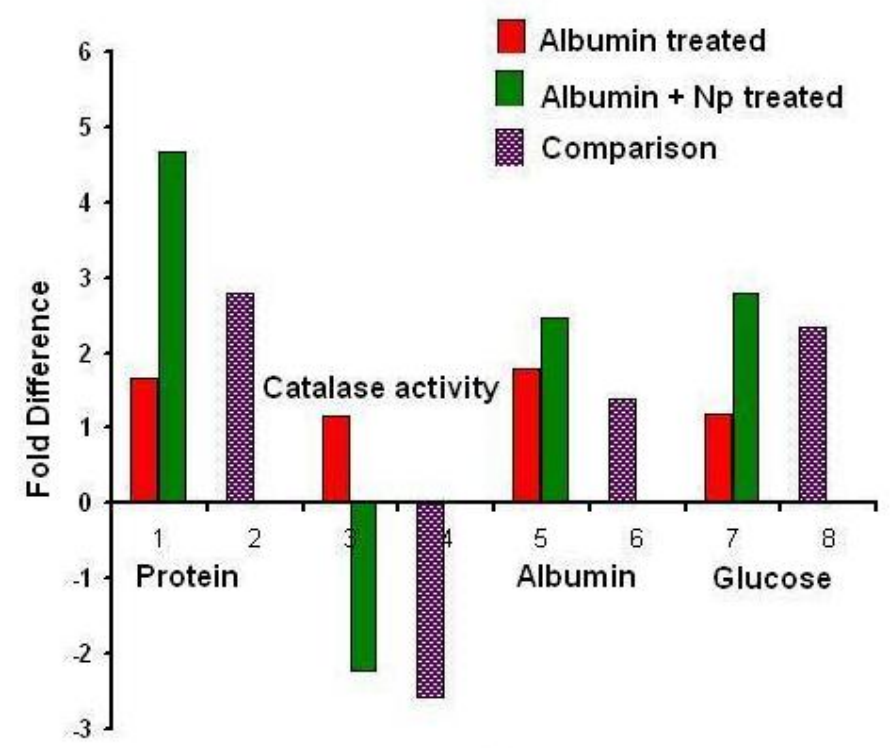

Factors

Figure 5. Comparative analysis of various biochemical factors like-protein, glucose, albumin and catalase activities of albumin with and without silver nanoparticles treated kidney cells and control cells in vitro

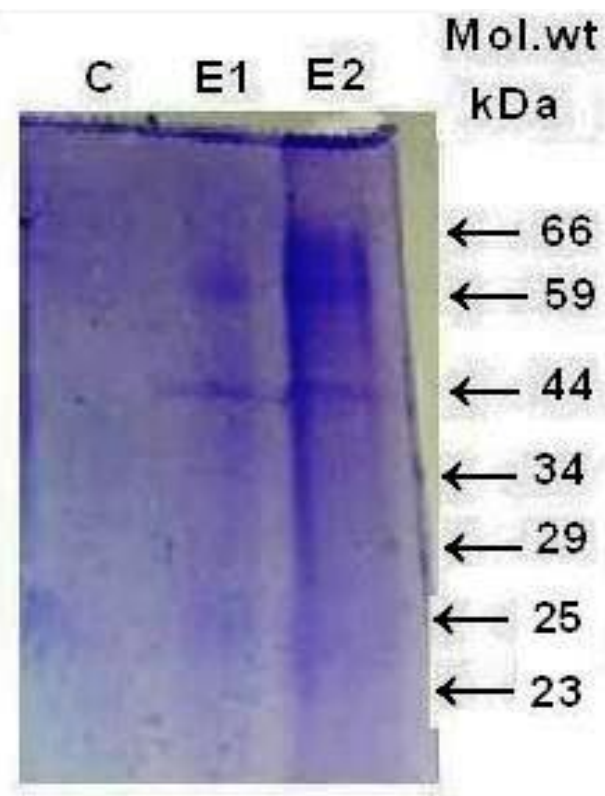

Figure 6. The protein profile pattern of albumin with and without silver nanoparticles treated (E1 and E2) kidney cells and control cells Lane 1 in vitro analyzed on $12.5 \%$ SDSPAGE

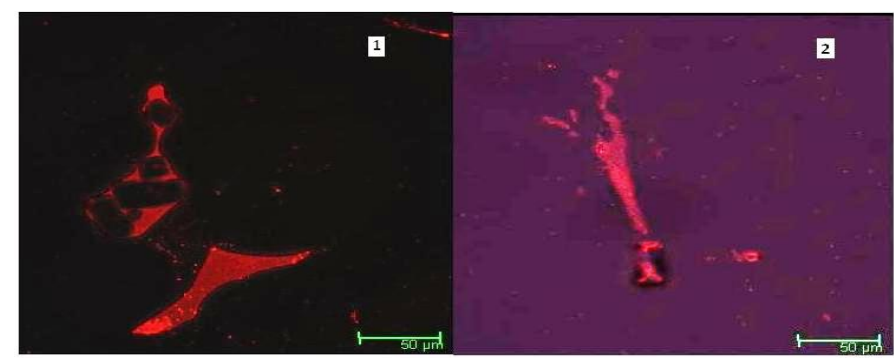

Figure 7. Confocal picture of Control (1) and albumin functionalized silver nanoparticle treated (2) kidney cells
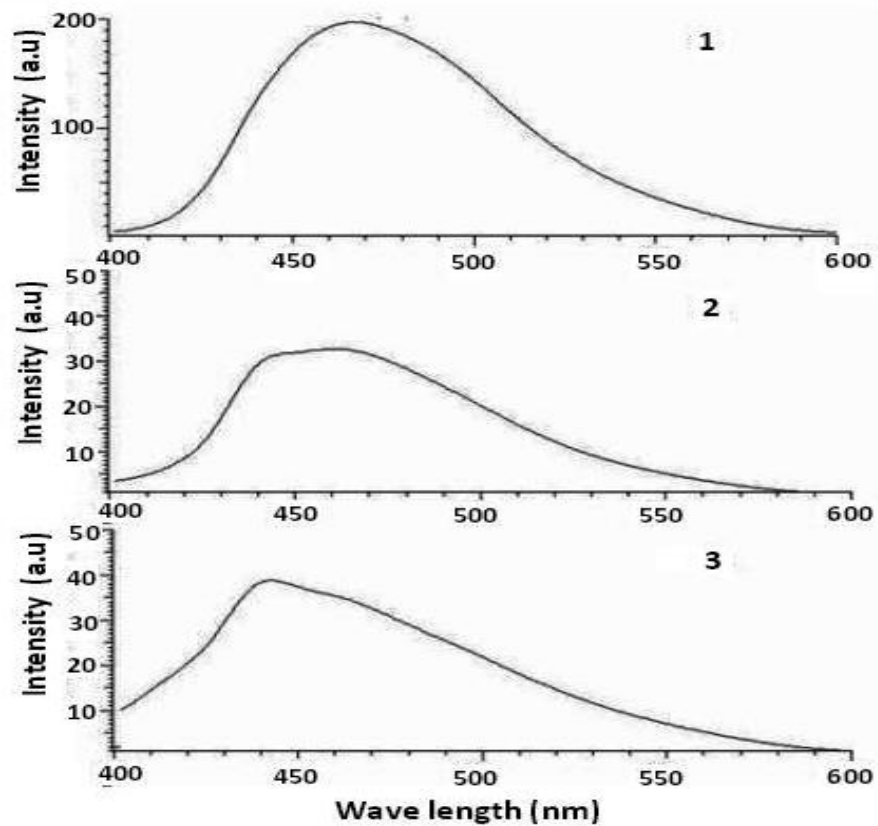

Figure 8. The fluorescence spectra of 1. Control 2. Albumin treated 3. Albumin- Silver nanoparticle treated kidney cells in vitro. 
uses the properties and physical characteristics of nanomaterials for the diagnosis and treatment of diseases [21]. In the present paper, the possible role of albumin functionalized silver nanoparticles in kidney cell metabolism was studied in vitro. Prior to that the blood samples collected from suspected kidney patients were studied.

In order to get a marker for early diagnostics and therapeutics, the blood samples collected from suspected kidney patients were analyzed for albumin level, protein level, glucose level and catalase activity (Figure 2). High levels of protein, glucose and albumin has been considered as a risk factor for the development of diabetes, nephropathy in patients with type II diabetes [22-24]. Glucose is reabsorbed by proximal tubular cells but are also responsible for the high intracellular accumulation, formation of advanced glycation end products [25] and an increased expression of collagen I/IV [26] in the glucotoxicity associated with diabetes

\section{In vitro Animal Studies}

The role of albumin in kidney cell metabolism was studied invitro and showed a profound influence of albumin with or without nanoparticles on the level of protein, glucose, and catalase activity. The albumin-nanoparticle treated cells were observed to be healthier as evidenced from the morphology of the cells.

Free radicals associated damage is an important factor in many pathophysiological processes like hypertension, anemia, arteriosclerotic cardiovascular disease, neurological disorders, hemostatic abnormalities, impaired immunity and chronic renal failure. Antioxidant activity as catalase activity was found to be low in the nanoparticle treated revealing less concentration of free radicals for scavenging. Elevated plasma concentration of enzyme defense and products were seen in chronic kidney failure CRF [27-30]. Both catalase and glutathione peroxidase proteins were down regulated in the chronic kidney failure $[19,31]$. Under physiological conditions, albumin may have significant antioxidant potential in the scavenging of oxygen free radicals, which have been implicated in the pathogenesis of inflammatory diseases. Physiological solutions of human serum albumin have been shown to inhibit the production of oxygen free radicals by polymorphonuclear leukocytes [32]. Antioxidant activity as catalase activity was found to be low in the nanoparticle treated revealing less concentration free radicals for scavenging [21,27,33,34].

The protein profile pattern of blood sample collected from suspected patients (Figure 3 ) showed low concentration of low molecular weight protein $(34,29,25$, and $23 \mathrm{kDa}$ protein) in two samples in contrast to the presence of high concentration of high molecular weight proteins compared to the control blood. The protein profile of kidney cells with and without nanotreatment in vitro (Figure 6) showed elevated level of high molecular weight protein $66 \mathrm{kDa}$ and $59 \mathrm{kDa}$ protein, $45 \mathrm{kDa}$ along with $34,29 \mathrm{kDa}$ protein (Lane E2) were observed

The kidney is the major site of catabolism for these proteins [35] and hence tubular malfunction results in elevated absorption and excretion. Albumin, $66 \mathrm{kDa}$ constitutes the major fraction of blood. The 74-76 kDa band may be transferring [36]. The two major proteins seen in $70 \mathrm{kDa}$ range are transferrin and Tamm Horsfall protein. Transferrin might be an indicator of glomerular proteinuria [37]. Albumin polymeric complexes may also be present in this range. Other proteins include IgG (160-200 kDa range) albumin polymers, IgA monomer and $\mathrm{C}$, the major proteins observed in blood of patients $300-400 \mathrm{kDa}$ range are fibrinogen and fibronectin. The expression of megalin 250-300 kDa and cubilin has been localized in rat and human podocytes [38-40].
The 55-65 bands may be al- antitrypsin, and the $45 \mathrm{kDa}$ protein band may be antiproteinase and Apoprotein A, of the HDL complex. The protein at band $25-26 \mathrm{kDa}$ may be retinol binding protein $(22$ $\mathrm{kDa})$ or light chain IgG and $\operatorname{IgA}(25 \mathrm{kDa})$ as commonly seen in urine of individuals with myeloma [41,42]. The a1-microglobulin (30-33 $\mathrm{kDa}$ ) and was found in patients with renal failure [43]. This protein was a good marker for tubular damage. The lowest sized band at 10-15 $\mathrm{kDa}$ may be a $\beta 2$-microglobulin $(12 \mathrm{kDa}$ ) were shown to be present in plasma and in the urine samples of patients with nephrotic syndrome $[43,44]$. The proteins with molecular weight $10-25 \mathrm{kDa}$ was reported to be related with the severity of tubular damage $[44,45]$.

The level of albumin endocytosis receptor megalin, in the proximal tubules was reported to decrease in diabetic rats [46]. Vesicular acidification by $\mathrm{H}^{+}$-ATPase, CLC-5, NHE-3 dissociates albumin and megalin and albumin reabsorption [47]. The role of heat shock proteins $(70 \mathrm{kDa}, 27 \mathrm{kDa}$ etc), in maintaining and restoring normal cellular function because of its potential anti-inflammatory properties [48-50] in the kidney in acute ischaemic kidney injury was reviewed by O'Neill, et al. [51]. It is reported that inhibition of Hsp90, mediate protection through induction of Hsp70 or NF- $\kappa B$ deactivation, and selective renal over expression of Hsp27 [52-54].

Understanding the morphology and physiology may provide the functional status of the the glomerular filtration barrier which includes podocyte and glomerulus along with extracellular matrix and basement membrane [55]. The in vitro studies revealed that the isolated kidney cells developed as an immature epithelial-like phenotype and their shape was like the shape of primary human kidney epithelial cells when cultured for 3-4 days without serum (Figure 4). Albumin endocytosis by podocytes visualized by confocal microscopy when cells were incubated with Rhodamine B-labelled albumin as described in methods (Figure 7)

The albumin uptake was enhanced in the podocyte cell body, Podocytes endocytose albumin and other proteins than control in vitro in the presence of statins and many fold accumulation of the proteins in proximal tubules than podocytes [55], possibly mediated by albumin receptors megalin [56], IgG, ferritin, and albumin, may be localized in podocyte vacuoles as reported earlier in human, rat, and mouse kidneys [55-63].

Podocyte integrity is essential for maintenance of an intact glomerular filtration barrier preventing albuminuria. Albumin endocytosis by mouse kidney cells visualized by confocal microscopy and fluorescence (Figures 7 and 8) showed no injury or damage. Our results unequivocally confirm the ability of podocytes to reabsorb protein by endocytosis and are in keeping with morphological observations that podocytes have many coated membrane pits and a large number of multivesicular bodies and other endosomal/lysosomal structures within their cell body, suggestive of high endocytic activity and vesicular trafficking $[64,65]$.

Tubular epithelial cells are known as very active cells that play an important role in the pathogenesis and progression of renal disease. They can produce a wide variety of inflammatory mediators, including cytokines [66,67] and chemokines, such as monocyte chemo attractant protein-1 (MCP-1), MCP-4. and osteopontin [68-70]. Recent studies suggest epithelial cells may also function as APC in the pathogenesis of nephritis. Costimulatory molecule ICAM-1 expression was reported for tubular epithelial cells [71,72]. Albumin bound silver nanoparticles showed high expression of high molecular weight proteins without any damage of the plasma membrane of renal cells (Figure 6) 
Sironmani TA (2018) Patho-physiological studies of human blood with kidney dysfunction and therapeutics of albumin functionalized silver nanoparticles in mice kidney cells in vitro

Albumin-nanoparticles have gained considerable attention owing to their high binding capacity of various drugs and being well tolerated without any serious side-effects [73-76]. The AgNPs has been known to be a potent antibacterial, antifungal and antiviral agent, AgNPS are used as therapeutic agents for the treatment of renal failure, cirrhosis, cardiovascular diseases, anticancer therapy, and diabetes and so on. The gold nanoclusters with small size was reported to penetrate kidney tissue and have promise to decrease in vivo toxicity by renal clearance [77]. Inorganic NPs exhibit long half-life, stronger signal outputs and more biomedical functionalities than other nanopreparations [33,34,78-80].

\section{Conclusion}

The high binding capacity of albumin along with the strong antimicrobial activity of silver nanoparticles are favourable aspects for drug delivery. The silver nanoparticles like gold nanoclusters can penetrate kidney tissue without toxicity for renal clearance. Our specialized nanoformulations are combination of herbal mineral extracts, albumin with silver nanoparticles eradicate the cause of Kidney Disorders rather than just suppressing the symptoms which will play a major role in the management of patients with kidney disease in the future.

\section{Acknowledgement}

This research did not receive any specific grant from funding agencies in the public, commercial, or not-for-profit sectors.

\section{References}

1. Friedman AN, Fadem SZ (2010) Reassessment of Albumin as a Nutritional Marker in Kidney Disease. J Am Soc Nephrol 21: 223-230.

2. World Health Organization (2009) Malnutrition. http://www.who.int/water_sanitation health/diseases/malnutrition/en/

3. Mitch WE (2002) Malnutrition: A frequent misdiagnosis for hemodialysis patients. $J$ Clin Invest 110: 437-439.

4. Foley RN, Parfrey PS, Harnett JD, Kent GM, Murray DC, et al. (1996) Hypoalbuminemia, cardiac morbidity, and mortality in end-stage renal disease. $J \mathrm{Am}$ Soc Nephrol 7: 728-736. [Crossref]

5. Stenvinkel P, Heimurger O, Paultre F, Diczfalusy U, Wang T, et al. (1999) Strong association between malnutrition, inflammation, and atherosclerosis in chronic renal failure. Kidney Int 55: 1899-1911. [Crossref]

6. Kalantar-Zadeh K, Kopple JD, Block G, Humphreys MH (2001) A malnutrition inflammation core is correlated with morbidity and mortality in maintenance hemodialysis patients. Am J Kidney Dis 38: 1251-1263. [Crossref]

7. Menon V, Greene T, Wang X, Pereira AA, Marcovina SM, et al. (2005) C-reactive protein and albumin as predictors of all-cause and cardiovascular mortality in chronic kidney disease. Kidney International 68: 766-772. [Crossref]

8. Joseph A, Eustace, Brad Astor, Paul M, Muntner T, et al. (2004) Prevalence of acidosis and inflammation and their association with low serum albumin in chronic kidney disease. Kidney International 65: 1031-1040.

9. Kellerman PS (1996) Cellular and metabolic consequences of chronic ischemia on kidney function. Semin Nephrol 16: 33-42.

10. Juillard L, Lerman LO, Kruger DG, Haas JA, Rucker BC, et al. (2004) Blood oxygen leveldependent measurement of acute intra-renal ischemia. Kidney Int 65: 944-950. [Crossref]

11. Brezis M, Agmon Y, Epstein FH (1994) Determinants of intrarenal oxygenation. Effects of diuretics. Am J Physiol 267: 1059-1062.

12. Fatica RA, Port FK, Young EW (2001) Incidence trends and mortality in end-stage renal disease attributed to renovascular disease in the United States. Am J Kidney Dis 37: 1184-1190. [Crossref]

13. Valderrabano F, Gomez-Campdera F, Jones EH (1998) Hypertension as cause of end-stage renal disease: Lessons from international registries. Kidney Int Suppl 68: S60-S66.

14. Grossman SB, Yap SH, Shafritz DA (1977) Influence of chronic renal failure on protein synthesis and albumin metabolism in rat liver. J Clin Invest 59: 869-878.
15. Ballmer PE, McNurlan MA, Hulter HN, Anderson SE, Garlick PJ, et al. (1995) Chronic metabolic acidosis decreases albumin synthesis and induces negative nitrogen balance in humans. J Clin Invest 95: 39-45. [Crossref]

16. Kaysen GA, Dubin JA, Muller HG, Rosales L, Levin NW, et al. (2004) Inflammation and reduced albumin synthesis associated with stable decline in serum albumin in hemodialysis patients. Kidney Int 65: 1408-1415.

17. Davies MJ, Fu S, Wang H, Dean RT (1999) Stable markers of oxidant damage to proteins and their application in the study of human disease. Free Radic Biol Med 27: 1151-1163. [Crossref]

18. Oberg BP, McMenamin E, Lucas FL, McMonagle E, Morrow J, et al. (2004) Increased prevalence of oxidant stress and inflammation in patients with moderate to severe chronic kidney disease. Kidney Int 65: 1009-1016. [Crossref]

19. Kobayashi M, Sugiyama H, Wang DH, Toda N, Maeshima Y, et al. (2005) Catalase deficiency renders remnant kidneys more susceptible to oxidant tissue injury and renal fibrosis in mice. Kidney Int 68: 1018-1031. [Crossref]

20. Ananth AN, Daniel SC, Sironmani TA, Umapathi S (2011) PVA and BSA stabilized silver nanoparticles-based surface enhanced plasmon resonance probes for protein detection. Colloids and Surfaces B: Biointerfaces 85: 138-144. [Crossref]

21. Anitha Sironmani T, Kiruba Daniel SCG (2011) Silver Nanoparticles - Universal Multifunctional Nanoparticles for Bio Sensing, Imaging for Diagnostics and Targeted Drug Delivery for Therapeutic Applications. In: Izet M. Kapetanovic eds. Drug Discovery and Development - Present and Future Book 1, InTech Publishers.

22. Fleck A, Raines G, Hawker F, Trotter J, Wallace PI, et al. (1985) Increased vascular permeability: A major cause of hypoalbuminaemia in disease and injury. Lancet 1 : 781-784.

23. Kaysen GA, Dubin JA, Muller HG, Rosales L, Levin NW, et al. (2004) Inflammation and reduced albumin synthesis associated with stable decline in serum albumin in hemodialysis patients. Kidney Int 65: 1408-1415.

24. Varma M, Sahu A, Kachhawa P, Jha RK (2014) Oxidative stress and Antioxidant Enzyme Levels in Hypertensive Chronic Kidney Disease patients. Inter J Biomed Ad Res 2014: 2229-3809.

25. Andersen S, Blouch K, Bialek J, Deckert M, Parving HH, et al. (2000) Glomerular permselectivity in early stages of overt diabetic nephropathy. Kidney Int 58: 2129 2137. [Crossref]

26. Ziyadeh FN, Snipes ER, Watanabe M, Alvarez RJ, Goldfarb S, et al. (1990) High glucose induces hypertrophy and stimulates collagen gene transcription in proximal tubules. Am J Physiol 259: F704-F714.

27. Kiruba Daniel SCG, Tharmaraj V, Anitha Sironmani T, Pitchumani K (2010) Toxicity and immunological activity of silver nanoparticles. Applied Clay Science 28: 547-551.

28. Trznadel K, Pawlicki L, Kedziora J, Luciak M, Blaszczyk J, et al. (1989) Superoxide anion generation, erythrocytes superoxide dismutase activity, and lipid peroxidation during hemoperfusion and hemodialysis in chronic uremic patients. Free Radic Biol Med 6: 393-397

29. Paul JL, Man NK, Moatti N, Raichvarg D (1991) Membrane phospholipid peroxidation in renal insufficiency and chronic hemodialysis. Nephrologie 12: 4 -7.

30. Vaziri ND, Oveisi F, Ding Y (1998) Role of increased oxygen free radical activity in the pathogenesis of uremic hypertension. Kidney Int 53: 1748- 1754.

31. Sindhu RK, Ehdaie A, Farmand F, Dhaliwal KK, Nguyen T, et al. (2005) Expression of catalase and glutathione peroxidase in renal insufficiency. Biochim et Biophy Acta 1743: 86-92. [Crossref]

32. Holt ME (1984) Albumin inhibits human polymorphonuclear leukocyte luminaldependent chemiluminescence: Evidence for oxygen radical scavenging. $B r J$ Exp Pathol 65: 231-241.

33. kiruba Daniel SCG, Anitha Sironmani T, Tharmaraj V, Pitchumani K (2011) Synthesis and Characterization of fluorophore attached silver nanoparticles. Bulletin of Materials Science 34: 639-643.

34. Anitha Sironmani T (2016) Therapeutic Potential of Neem Synthesized Silver Nanoparticles on Human Gastric Cancer Cells in Vitro. World Journal of Nano Science and Engineering 6: 90-110.

35. Strober W, Waldmann TA (1974) The role of the kidney in the metabolism of plasma proteins. Nephron 13: 35-66. [Crossref]

36. Yalcin A, Cetin M (2013) Electropheretic separation of urine proteins of healthy dogs and dogs with nephropathy and detection of some urine proteins of dogs using immunoblotting. Thai J Vet Med 43: 75-83.

37. Stierle HE, Oser B, Boesken WH (1990) Improved classification of proteinuria by semiautomated ultrathin SDS-polyacrylamide gel electrophoresis. Clin Nephrol 33: 168-173. 
Sironmani TA (2018) Patho-physiological studies of human blood with kidney dysfunction and therapeutics of albumin functionalized silver nanoparticles in mice kidney cells in vitro

38. Gekle M, Mildenberger S, Freudinger R, Silbernag S (1995) Endosomal alkalinization reduces $\mathrm{J}(\max )$ and $\mathrm{K}(\mathrm{m})$ of albumin receptor- mediated endocytosis in OK cells. American J Physiol 268: F899-906.

39. Onozato ML, Tojo A, Leiper J, Fujita T, Palm F, et al. (2008) Expression of NG, NGdimethylarginine dimethyl amino hydrolase and protein arginine N-methyl transferase isoforms in diabetic rat kidney effects of angiotensin II receptor blockers. Diabetes 57: $172-180$.

40. Tojo A, Tisher CC, Madsen KM (1994) Angiotensin II rregulates H+-ATPase activity in rat cortical collecting duct. American J Physiol 267: F1045- 1051.

41. Outteridge PM (1985) Veterinary Immunology, Academic Press, London, pp: 14-15.

42. Bemier GM, Putnam FW (1964) Polymerism, polymorphism, and impurities in Bence Jones proteins. Biochim Biophys Acta 86: 295-308.

43. Yu H, Yanagisawa Y, Forbes MA, Cooper EH, Crockson RA, et al. (1983) Alpha-1microglobulin: an indicator protein for renal tubular function. J Clin Pathol 36: 253259. [Crossref]

44. Tomlinson PA (1992) Low molecular weight proteins in children with renal disease. Pediatr Nephrol 6: 565-571.

45. Bazzi C, Petrini C, Rizza V, Arrigo G, D'Amico G (2000) A modern approach to selectivity of proteinuria and tubule-interstitial damage in nephrotic syndrome. Kidney Int 58: 1732-1741.

46. Tojo A, Onozato M, Ha H, Kurihara H, Sakai T, et al. (2001) Reduced albumin reabsorption in the proximal tubule of early-stage diabetic rats. Histochem Cell Biol 116: $269-276$.

47. Gekle M, Mildenberger S, Freudinger R, Silbernagl S (1993) Endosomal alkalinization reduces $\mathrm{J}(\max )$ and $\mathrm{K}(\mathrm{m})$ of albumin receptor- mediated endocytosis in OK cells. $\mathrm{Am}$ J Physiol 268: F899-906.

48. Marzec L, Zdrojewski Z, Liberek T, Bryl E, Chmielewski M, et al. (2009) Expression of Hsp72 protein in chronic kidney disease patients. Scandinavian J Urol Nephrol 143: 400-408. [Crossref]

49. Wang Z, Gall JM, Bonegio RG, Havasi A, Hunt CR, et al. (2011) Induction of heatshock protein 70 inhibits ischemic renal injury. Kidney Int 79: 861-870.

50. Kim M, Park SW, Chen SW, Gerthoffer WT, D'Agati VD, et al. (2010) Selective renal overexpression of human heat-shock protein 27 reduces renal ischemia-reperfusion injury in mice. Am J Physiol Renal Physiol 299: F347-358.

51. O’Neill S, Harrison EM, Ross JA, Wigmore SJ, Hughes J (2014) Heat-Shock Proteins and Acute Ischaemic Kidney Injury. Nephron Exp Nephrol 126: 167-174.

52. O'Neill S, Ross JA, Wigmore SJ, Harrison EM (2012) The role of heat-shock protein 90 in modulating ischemia-reperfusion injury in the kidney. Expert Opin Investig Drugs 21: 1535-1548.

53. Harrison EM, Sharpe E, Bellamy CO, McNally SJ, Devey L, et al. (2008) Heat-shock protein 90-binding agents protect renal cells from oxidative stress and reduce kidney ischemia-reperfusion injury. Am J Physiol Renal Physiol 295: F397- 405.

54. Bonventre JV, Yang L (2011) Cellular pathophysiology of ischemic acute kidney injury. J Clin Invest 121: 4210-4221. [Crossref]

55. Eyre J, Ioannou K, Grubb BD, Saleem MA, Mathieson PW, et al. (2007) Statinsensitive endocytosis of albumin by glomerular podocytes. Am J Physiol Renal Physiol 292: F674-681. [Crossref]

56. Tojo A, Kinugasa S (2012) Mechanisms of Glomerular Albumin Filtration and Tubular Reabsorption. Japan J Nephrol.

57. Akilesh S, Huber TB, Wu H, Wang G, Hartleben B, et al. (2008) Podocytes use FcRn to clear IgG from the glomerular basement membrane. Proc Natl Acad Sci USA 105: 967-972. [Crossref]

58. Kinugasa S, Tojo A, Sakai T, Tsumura H, TakahashiM, et al. (2011) Selective albuminuria via podocyte albumin transport in puromycin nephrotic rats is attenuated by an inhibitor of NADPH oxidase. Kidney Int 80: 1328-1338.

59. Farquhar MG, Palade GE (1961) Glomerular permeability. II. Ferritin transfer across the glomerular capillary wall in nephrotic rats. J Exp Med 114: 699-716.

60. Ina K, Kitamura H, Tatsukawa S, Takayama T, Fujikura Y (2002) Glomerular podocyte endocytosis of the diabetic rat. J Electron Microsc (Tokyo) 51: 275-279.

61. Tojo A, Onozato ML, Kitiyakara C, Kinugasa S, Fukuda S, et al. (2008) Glomerular albumin filtration through podocyte cell body in puromycin aminonucleoside nephrotic rat. Med Mol Morphol 41: 92-98.
62. Christensen EI, Zhou Q, Sørensen SS, Rasmussen AK, Jacobsen C, et al. (2007) Distribution of alpha-galactosidase A in normal human kidney and renal accumulation and distribution of recombinant alpha-galactosidase A in Fabry mice. $J$ Am Soc Nephrol 18: 698-706.

63. Kinugasa S, Tojo A, Sakai T, Fujita T (2010) Silver-enhanced immunogold scanning electron microscopy using vibratome sections of rat kidneys: Detection of albumin filtration and reabsorption. Med Mol Morphol 43: 218-225.

64. Galaske RG, Vanliew JB, Boylan JW (1975) Urinary protein excretion in the rat: Strain and age dependence. The Physiologist 18: 222.

65. Noonan WT, Shapiro VM, Banks RO (2011) Renal glucose reabsorption during hypertonic glucose infusion in female streptozotocin-induced diabetic rats. Life Sci 68: 2967-2977.

66. Kelley VR, Diaz-Gallo C, Jevnikaram Singer GG (1993) Renal tubular epithelial and T cell interactions in autoimmune renal disease. Kidney Int 43: S108-S115.

67. Brauner A, Soderhall M, Jacobson SH, Lundahl J, Andersson U, et al. (2001) Escherichia coli induced expression of IL-1 alpha, IL-1 beta, IL-6 and IL-8 in normal human renal tubular epithelial cells. Clin Exp Immunol 124: 423- 428. [Crossref]

68. Chakravorty SJ, Howie AJ, Girdlestone J, Gentle D, Savage CO (2001) Potential role for monocyte chemotactic protein-4 (MCP-4) in monocyte/ macrophages recruitment in acute renal inflammation. J Pathol 194: 239-246. [Crossref]

69. Prodjosudjadi W, Gerritsma JS, VanEs LA, Daha MR, Bruijn JA (1995) Monocyte chemoattractant protein-1 in normal and diseased human kidneys: An immunohistochemical analysis. Clin Nephrol 44: 148-155. [Crossref]

70. Okada H, Moriwaki K, Konishi K, Kobayashi T, Sugahara S, et al. (2000) Tubular osteopontin expression in human glomerulonephritis and renal vasculitis. Am J Kidney Dis 36: 498-506. [Crossref]

71. Wagrowska Danilewicz M, Danilewicz M (1998) Intercellular adhesion molecule-1 (ICAM-1), leucocyte function-associated antigen-1 (LFA-1) and leucocyte infiltration in proliferative human glomerulo- nephritis. Acta-Histochem 100: 201-215.

72. Arrizabalaga P, Sole M, Abellana R, Ascaso C, Cardesa A (2001) Renal expression of intercellular adhesion molecule-1 in immunoglobulin A nephropathy: Tubulointerstitial injury and prognosis. Virchowa Arch 439: 27- 34.

73. Elzoghby AO, Samy WM, Elgindy NA (2012) Albumin-based nanoparticles as potential controlled release drug delivery systems. J Control Release 157: 168-182. [Crossref]

74. Wartlick H, Spänkuch-Schmitt B, Strebhardt K, Kreuter J, Langer K (2004) Tumour cell delivery of antisense oligonuclceotides by human serum albumin nanoparticles. $J$ Control Release 96: 483-495.

75. Ulbrich K, Michaelis M, Rothweiler F, Knobloch T, Sithisarn P, et al. (2011) Interaction of folate-conjugated human serum albumin (HSA) nano-particles with tumor cells. Int J Pharm 406: 128-134.

76. Damascelli B, Cantuand̀ G, Mattavelli F, Tamplenizza P, Bidoli P, et al. (2001) Intraarterial chemotherapy with polyoxyethylated castor oil free paclitaxel, incorporated in albumin nanoparticles (ABI-007): Phase I study of patients with squamous cell carcinoma of the head and neck and anal canal: Preliminary evidence of clinical activity. Cancer 92: 2592-2602.

77. Wu D, Zhang XD, Liu PX, Zhang LA, Fan FY, et al. (2011) Gold nanostructure fabrication, surface modification, targeting imaging, and enhanced radiotherapy. Curr Nanosci 7: 110-118.

78. Hardman R (2006) A toxicologic review of quantum dots: toxicity depends on physicochemical and environmental factors. Environ Health Perspect 114: 165-172.

79. Yong KT, Law WC, Hu R, Ye L, Liu L, et al. (2013) Nanotoxicity assessment of quantum dots: from cellular to primate studies. Chem Soc Rev 42: 1236-1250. [Crossref]

80. Anitha Sironmani T (2017) Immuno - Functionalized Silver Nanoparticles for Diagnostics, Therapeutics and Protection of Rabies Viral Infection. Curr Nanomed 7: 73-82.

Copyright: (C2018 Sironmani TA. This is an open-access article distributed under the terms of the Creative Commons Attribution License, which permits unrestricted use, distribution, and reproduction in any medium, provided the original author and source are credited. 